Marta Bożym*

\title{
Heavy metal content in compost and earthworms from home composters
}

\section{Zawartość metali ciężkich w kompostach i ciałach dżdżownic pochodzących z przydomowych kompostowników}

\footnotetext{
* Dr inż. Marta Bożym, Opole University of Technology; 76 Prószkowska

Street, 45-758 Opole, Poland; e-mail: m.bozym@po.opole.pl
}

Keywords: heavy metals, compost, earthworms, green waste, composters, bioaccumulation factor (BAF)

Słowa kluczowe: metale ciężkie, kompost, dżdżownice, odpady zielone, kompostowniki, współczynnik biokumulacji (BAF)

\begin{abstract}
The paper presents the results of compost tests from home composters and earthworms living there, that treating waste into compost. The samples were taken from home composters and allotment gardens from Opole Region. The composting material was green waste. The total content of heavy metals $(\mathrm{Cd}, \mathrm{Pb}$, $\mathrm{Cu}, \mathrm{Zn}, \mathrm{Ni} \mathrm{Cr}$ ) in compost and compost earthworms' samples were determined. It was found that the compost samples were not contaminated with heavy metals. According to the Polish classification of composts from municipal wastes, the composts met the requirements for first class of quality. The composts did not exceed the limits of heavy metals specified in the Polish law for solid organic fertilizers. The degree of metal accumulation by compost earthworms depended on the type of metal. The high value of the bioaccumulation factor (BAF) was obtained for $\mathrm{Cd}, \mathrm{Pb}$ and $\mathrm{Zn}$. No accumulation of other metals $(\mathrm{Ni}, \mathrm{Cr}, \mathrm{Cu})$ in earthworm bodies was found. It has been found that earthworm species, naturally occurring in Poland, can also be used as potential bioindicators of metals in the environment, such as the species Eisenia fetida. The aim of the study was to evaluate the heavy metal content in composts from home composters and ability to accumulate metals by compost earthworms.
\end{abstract}

๑) IOŚ-PIB

\section{INTRODUCTION}

Composting is one of the most preferred methods of solid waste management principally due to the high percentage of organic matter [Mohee, Soobhany 2014]. A variant of the composting of wastes is the use of earthworms in the vermicompost process. The earthworms degrade and homogenise the organic material and indirectly increase the surface area for microbial action [Bożym 2016]. The mutual reaction of earthworms and aerobic microbes accelerates the biodegradation of organic wastes. Besides, after passing through the intestines, there are many useful microorganisms in the coprolite [Gajewska et al. 2007]. The vermicomposting process is used to treat the sewage sludge [Bożym 2004, 2012, 2014, 2016]. This process involves the stabilization of organic matter through earthworm consumption that converts the waste into high quality fertilizer [Mohee, Soobhany 2014, Suleiman et al. 2017].

\section{Streszczenie}

W pracy przedstawiono wyniki badań kompostów pochodzących z przydomowych kompostowników oraz żyjących tam dżdżownic, które biorą udział w przetwarzaniu odpadów. Próbki pobrano z kompostowników przydomowych oraz z ogrodów działkowych Opolszczyzny. Kompostowanym materiałem były odpady zielone. W próbkach kompostów i dżdżownicach oznaczono ogólną zawartość metali ciężkich ( $\mathrm{Cd}, \mathrm{Pb}, \mathrm{Cu}, \mathrm{Zn}, \mathrm{Ni} \mathrm{Cr}$ ). Stwierdzono, że komposty nie były zanieczyszczone metalami ciężkimi. Zgodnie z polską klasyfikacją kompostów z odpadów miejskich, badane komposty spełniają normy dla I klasy jakości. W kompostach nie zostały przekroczone graniczne wartości metali ciężkich określone w polskim prawie dla stałych nawozów organicznych. Stopień kumulacji metali przez dżdżownice kompostowe zależała od rodzaju metalu. Wysoką wartość współczynnika kumulacji BAF uzyskano dla $\mathrm{Cd}, \mathrm{Pb}$ i Zn. Pozostałe metale (Ni, $\mathrm{Cr}, \mathrm{Cu})$ nie były kumulowane $w$ ciałach dżdżownic. Stwierdzono, że gatunki dżdżownic, wolnożyjące, naturalnie występujące w Polsce, mogą także być wykorzystywane jako potencjalne bioindykatory metali w środowisku, podobnie jak gatunek Eisenia fetida. Celem pracy było badanie zawartości metali ciężkich w kompostach z domowych kompostowników oraz stopnia gromadzenie metali przez dżdżownice kompostowe.

The application of compost could potentially contaminate the environment with heavy metals. The environmental problem with heavy metals is that they are unaffected during the degradation of organic waste. The compost could be used as fertilizer and the heavy metals may be subjected to bioaccumulation and cause risk to animals and humans when transferred to the food chain [Mohee, Soobhany 2014]. The problem of heavy metal pollution concerns mainly composts from municipal waste and sewage sludge used as fertilizer [Bożym, Rajmund 2015, Hadam, Obidoska 2009, Kucharczak et al. 2010]. The toxicity of metals is influenced by their chemical form. Various extraction methods are used to assess the bioavailability and mobility of metals in soil, composts, sewage sludge and others, [Bożym, Rajmund 2015, Jeske, Gworek 2011, Rao et al. 2008]. Compost from green waste is not a threat to the environment. Due to the susceptibility 
of earthworms to high concentrations of heavy metals in the soil or compost, they are often used as bioindicators of environmental pollution. Eisenia fetida species of earthworm is most commonly used as a bioindicator [Bożym 2005, 2014, Li et al. 2010]. The $B A F$ (Bio Accumulation Factor) are used to calculate the degree of metal accumulation by earthworms, [Dai et al. 2004, Li et al. 2010, Saxe et al. 2001, Suleiman et al. 2017]. It is well recognized that accumulation of heavy metal in earthworms depends strongly on not only the total metal content and $\mathrm{pH}$ and organic carbon content [Bożym 2012, 2014, Ma 2004], but also on the species and stage of development of the earthworm (adults) [Ma 2004, Suleiman et al. 2017]. According to Suleiman et al. [2017], Dendrobaena veneta exhibited much lower resistance to toxic effects of heavy metals in composted sewage sludge than other species: Eisenia fetida, Eisenia andrei. It has been found that earthworms could not regulate metal uptake. However, there is a phenomenon of food selectivity by earthworms [Bożym 2005, 2012].

The aim of the study was to evaluate the heavy metal content in composts and ability to accumulate metals by compost earthworms from home composters. In addition, the bio-accumulation factor (BAF) of metals by compost earthworms and the confirmation of their usefulness as bioindicators were investigated.

\section{MATERIAL AND METHODS}

The samples were taken from home composters and allotment gardens from Opole Region. The composting material was only green waste such as vegetable and fruit waste, leaves, branches and so on. The total content of heavy metals $(\mathrm{Cd}, \mathrm{Pb}, \mathrm{Cu}, \mathrm{Zn}, \mathrm{Ni}$ $\mathrm{Cr}$ ) in compost and compost earthworm samples were determined using the FAAS method after mineralisation with aqua-regia. The 15 open composters, fenced with boards or concrete walls, with a capacity of $1-10 \mathrm{~m}^{3}$ were selected. The samples were taken three times at monthly intervals in July, August and September 2016. Composted material $(1 \mathrm{~kg}$ ) and earthworms (> 10 adults) were collected from the bottom of the composters. In the laboratory, the compost was homogenized, dried at $105^{\circ} \mathrm{C}$ and powdered in a mortar. The adult earthworms were washed with deionized water and placed in plastic containers with a few pieces of wet lignin. In order to void their guts, the earthworms were kept on the moist lignin for $48 \mathrm{~h}$ without food. Earthworms were killed by acetone, dried at $105^{\circ} \mathrm{C}$ and powdered in a mortar. All the samples were digested by aqua regia in a microwave digestion system Milestone Start D in closed Teflon bombs and measured by flame atomic absorption spectrometry (FAAS, Solaar 6M Thermo). Bioaccumulation factor $(B A F)$ of metals was calculated according to Eq. (1).

$$
B A F=\frac{[\text { metal }]_{\text {earthworm }[}[\mathrm{mg} / \mathrm{kg}]}{[\text { metal }]_{\text {compost }}[\mathrm{mg} / \mathrm{kg}]}
$$

where:

$B A F$ represents bioaccumulation factor,

[metal] $]_{\text {earthworm }}$ represents the total metal concentration of earthworm $[\mathrm{mg} / \mathrm{kg}]$,

[metal] $]_{\text {compost }}$ represents the total metal concentration of compost $[\mathrm{mg} / \mathrm{kg}]$.
The results were presented as the mean of the three replicates. For quality control of total metal content determination in the samples, a certified reference material (CRM) 'Sewage sludge amended soil' CRM005-050 was analysed. The recovery of metals content in CRM were respectively: Cd 96\%, $\mathrm{Pb} 95 \%, \mathrm{Cu}$ 95\%, Zn 97\%, Cr 95\%, and Ni 95\%.

\section{RESULTS AND DISCUSSION}

The heavy metal content in the compost in comparison to the Polish standards for first class of compost from municipal waste and limitation for solid organic fertilizers was presented in table 1. Table 2 shows the heavy metals content in the earthworms' bodies.

Table 1. The mean, SD and range of heavy metals in compost samples and earthworms [mg/kg d.m.].

\begin{tabular}{|c|c|c|c|}
\hline \multirow{2}{*}{ metal } & \multirow{2}{*}{$\begin{array}{l}\text { type of } \\
\text { sampling } \\
\text { compost } \\
(n=15)\end{array}$} & \multicolumn{2}{|c|}{$\begin{array}{l}\text { Limit values according to } \\
\text { Polish law }\end{array}$} \\
\hline & & $\begin{array}{l}\text { I class of } \\
\text { compost* }^{*}\end{array}$ & $\begin{array}{l}\text { solid organic } \\
\text { fertilizers }\end{array}$ \\
\hline $\begin{array}{l}\text { Cd } \\
\text { range } \\
\text { mean } \\
\text { SD }\end{array}$ & $\begin{array}{c}0.20-0.70 \\
\mathbf{0 . 4 9} \\
0.13\end{array}$ & 5 & 5 \\
\hline $\begin{array}{l}\mathrm{Pb} \\
\text { range } \\
\text { mean } \\
\mathrm{SD}\end{array}$ & $\begin{array}{c}17.3-28.5 \\
20.8 \\
3.0\end{array}$ & 350 & 140 \\
\hline $\begin{array}{l}\mathrm{Cu} \\
\text { range } \\
\text { mean } \\
\text { SD }\end{array}$ & $\begin{array}{c}22.1-49.8 \\
36.0 \\
8.9\end{array}$ & 300 & no limited \\
\hline $\begin{array}{l}\mathrm{Zn} \\
\text { range } \\
\text { mean } \\
\text { SD }\end{array}$ & $\begin{array}{c}144-388 \\
240 \\
83\end{array}$ & 1500 & no limited \\
\hline $\begin{array}{l}\mathrm{Cr} \\
\text { range } \\
\text { mean } \\
\mathrm{SD}\end{array}$ & $\begin{array}{c}7.8-25.6 \\
14.9 \\
6.2\end{array}$ & 300 & 100 \\
\hline $\begin{array}{l}\mathrm{Ni} \\
\text { range } \\
\text { mean } \\
\mathrm{SD}\end{array}$ & $\begin{array}{c}12.8-34.5 \\
17.0 \\
6.0\end{array}$ & 100 & 60 \\
\hline
\end{tabular}

*- requirements for I class of quality of compost from municipal wastes [BN-89/9103-090]

** - limit values for solid organic fertilizers according to [Rozporządzenie...2008]

Cadmium content in compost samples ranged: $0.20-0.70 \mathrm{mg} /$ $\mathrm{kg}$ (mean $0.49 \mathrm{mg} / \mathrm{kg}$ ). The earthworms accumulated cadmium; the content of cadmium in the earthworms' bodies were higher $(0.31-5.22 \mathrm{mg} / \mathrm{kg})$ than in the compost. The range of lead content in composts were within 17.3 to $28.5 \mathrm{mg} / \mathrm{kg}$ (mean 20.8 $\mathrm{mg} / \mathrm{kg}$ ) (Table 1). The range of $\mathrm{Pb}$ content in the earthworms' 
Table 2. The heavy metals concentration (range, mean, SD) in earthworms' bodies [mg/kg].

\begin{tabular}{|c|c|c|c|c|c|c|}
\hline metal & $\mathbf{C d}$ & $\mathbf{P b}$ & $\mathbf{C u}$ & $\mathbf{Z n}$ & $\mathbf{C r}$ & $\mathbf{N i}$ \\
\hline range & $0.31-5.22$ & $14.6-37.5$ & $2.8-13.7$ & $98-333$ & $2.2-8.5$ & $3.5-15$ \\
mean & 1.18 & $\mathbf{2 3 , 0}$ & $\mathbf{7 . 2}$ & $\mathbf{1 9 0}$ & 4.3 & $\mathbf{8 . 7}$ \\
SD & 1.41 & 8,3 & 3.1 & 78 & 2.1 & $3 . .6$ \\
\hline
\end{tabular}

Table 3. Bioaccumulation factor $(B A F)$ of metals in earthworms $(n=15)$

\begin{tabular}{|c|c|c|c|c|c|c|}
\hline metal & $\mathbf{C d}$ & $\mathbf{P b}$ & $\mathbf{C u}$ & $\mathbf{Z n}$ & $\mathbf{C r}$ & $\mathbf{N i}$ \\
\hline range & $0.7-12.2$ & $0.8-2.2$ & $0.1-0.3$ & $0.3-1.3$ & $0.2-0.6$ & $0.2-0.8$ \\
\hline mean & $\mathbf{2 . 5}$ & $\mathbf{1 . 2}$ & $\mathbf{0 . 2}$ & $\mathbf{0 . 8}$ & $\mathbf{0 . 3}$ & $\mathbf{0 . 5}$ \\
\hline $\mathrm{SD}$ & 3.3 & 0.5 & 0.1 & 0.2 & 0.2 & 0.2 \\
\hline
\end{tabular}

bodies was: $14.6-37.5 \mathrm{mg} / \mathrm{kg}$ (table 2). The copper content in the compost samples ranged from 22.1 to $49.8 \mathrm{mg} / \mathrm{kg}$ (mean $36.0 \mathrm{mg} / \mathrm{kg}$ ). Cu is classified as micronutrients and its content is not regulated in the guidelines for organic fertilizers. Earthworms did not accumulate copper, the content of this metal in the earthworms' bodies $(2.8-13.7 \mathrm{mg} / \mathrm{kg}$ ) was lower than that of the compost. The zinc content in compost samples ranged from 144 to $388 \mathrm{mg} / \mathrm{kg}$ (mean $240 \mathrm{mg} / \mathrm{kg}$ ). Zinc, similar to copper, is a microelement and its content is not limited to organic fertilizers. The $\mathrm{Zn}$ content in the earthworms' bodies was within limits: 98$333 \mathrm{mg} / \mathrm{kg}$. The chromium content of the compost varied within $7.8-25.6 \mathrm{mg} / \mathrm{kg}$ (mean $14.9 \mathrm{mg} / \mathrm{kg}$ ); however, the content of this metal in the bodies of earthworms was lower and ranged between $2.2-8.5 \mathrm{mg} / \mathrm{kg}$. Nickel in the compost samples was determined in the range of 12.8 to $34.5 \mathrm{mg} / \mathrm{kg}$ (mean $17.0 \mathrm{mg} / \mathrm{kg}$ ) and in the earthworms' bodies on lower level, from 3.5 to $15 \mathrm{mg} /$ $\mathrm{kg}$ (table 1 and 2).

The results showed no heavy metal contamination of the analysed compost. According to the Polish classification of composts from municipal wastes, the composts met the requirements for first class of quality [BN-89/9103-090]. The composts did not exceed the limits of heavy metals specified in the Polish law for solid organic fertilizers (Table 1) [Rozporządzenie...2008]. Similar results of metal content in the composts from Opole home composters have been obtained by Ciesielczuk and Kusza [2009]: Cd 0.50-0.94 $\mathrm{mg} / \mathrm{kg}, \mathrm{Pb}$ 19.3-33.0 mg/kg, Zn 168-277 mg/kg, and Ni 11.1-16.5 $\mathrm{mg} / \mathrm{kg}$. The authors received higher content of $\mathrm{Cr}(15-80 \mathrm{mg} /$ $\mathrm{kg}$ ) and $\mathrm{Cu} 23-80 \mathrm{mg} / \mathrm{kg}$. The content of metals in composts is affected by the contamination of substrate. Heavy metal content in composts from municipal waste or sewage sludge is usually much higher than from green waste [Ciesielczuk and Kusza 2009]. Further, an analysis of the bio-accumulation factor (BAF) was conducted to assess the extent of metals' accumulation by earthworm. The results are given in Table 3.

$B A F$ refers to the bioavailable concentration, operationally reflecting the efficiency of sentinel organisms as bioconcentrators of any given metal [Dai et al. 2004, Li et al. 2010, Saxe et al. 2001]. If the value exceeds 1 , this means that the earthworms have the ability to accumulate metal. Earthworms are often used as bioindicators of metal, due to their ability to accumulate these pollutants and their high resistance to toxicity. The adult earthworm was speculated to have such an ability to store high concentrations of heavy metals in the non-toxic forms [ $\mathrm{Li}$ et al.
2010]. It has been shown that the species Eisenia fetida have a high ability for metal accumulation, which is also used to treat sewage sludge [Bożym 2004, 2012, 2014, 2016, Li et al. 2010]. In addition, earthworms living in the soil have such an ability. Broma et al. [2009] confirmed the ability of two species of earthworms (Dendrobaena veneta, Lumbricus terrestris) to accumulate heavy metals. They have proven that accumulation depends on the concentration of metals in the soil.

As shown in Table 3, the BAF of Cd were much higher than 1 . For one compost sample, the $B A F(C d)$ high value was calculated as 12.2. The ability to accumulate cadmium by earthworms is confirmed by the results obtained for Eisenia fetida species processing manure and sludge [Bożym 2014, Li et al. 2010]. The BAF value for lead was calculated to be approximately 1 for all samples. Only in few cases, $B A F(\mathrm{~Pb})$ exceeded 1. Lead is a metal that is not toxic to earthworms due to its calcium affinity. Lead accumulates in limestone glands and is readily excreted in a non-toxic form. For this reason, the degree of lead accumulation in earthworms may be low. As in the case of lead, the $B A F$ value for zinc was in most cases close to 1 , which means that the content in the compost was close to that in the earthworms. For other metals, that is, $\mathrm{Cu}, \mathrm{Cr}$, and $\mathrm{Ni}$, no ability to accumulate these metals by earthworms was found. The BAFs of these metals were less than 1 in all cases. For analysed composting earthworms, BAFs were in the following order: $\mathrm{Cd}>\mathrm{Pb}>\mathrm{Zn}>$ $\mathrm{Ni}, \mathrm{Cr}, \mathrm{Cu}$. According to Bożym [2014], the BAF for Eisenia fetida from sewage sludge was arranged as follows: $\mathrm{Cd}>\mathrm{Ni}>\mathrm{Zn}>\mathrm{Pb}$ $=\mathrm{Cu}>\mathrm{Cr}$, whereas according to Suleiman et al. [2017], it was: $\mathrm{Cd}>\mathrm{Co}>\mathrm{Cu}>\mathrm{Zn}>\mathrm{Ni}>\mathrm{Pb}>\mathrm{Cr}$.

\section{CONCLUSIONS}

No contamination of heavy metals in compost from home composters was found. Therefore, according to the Polish classification of composts from municipal waste, the composts belonged to class I quality. Furthermore, the composts did not exceed the limits of heavy metals, specified in the Polish law for solid organic fertilizers. The metal content in the earthworms depended on the type of metal. The high bioaccumulation factors (BAFs) of earthworm to heavy metals were calculated for $\mathrm{Cd}(2.2)$ and $\mathrm{Pb}$ (1.2). The content of zinc in earthworms was calculated as 0.8 . The contents of other metals $(\mathrm{Cu}, \mathrm{Ni}, \mathrm{Cr})$ were lower 
$(0.2-0.5)$, this proves no ability to accumulate these metals by earthworms. It has been found that the earthworm species, naturally occurring in Poland, can also be used as potential bioindicators of metals in the environment, such as the species Eisenia fetida.

\section{REFERENCES AND LEGAL ACTS}

BN-89/9103-090. Unieszkodliwianie odpadów miejskich. Kompost $z$ odpadów miejskich.

BOŻYM M. 2004. Zmiany parametrów fizykochemicznych osadu ściekowego w czasie wermikompostowania, Zeszyty Problemowe Postępów Nauk Rolniczych 498: 33-39.

BOŻYM M. 2005. Wpływ metali ciężkich na życie dżdżownic, Biuletyn Naukowy 25, 1: 201-210.

BOŻYM M. 2012. Biologiczne przetwarzanie biodegradowalnej frakcji odpadów komunalnych i osadów ściekowych w wermikulturze. Prace Instytutu Ceramiki i Materiałów Budowlanych 10: 335-369.

BOŻYM M. 2014. Kumulacja metali ciężkich przez dżdżownice w wermikompostowanych osadach ściekowych. Chemik 68, 10: 868-875.

BOŻYM M. 2016. Wermikompostowanie osadów ściekowych. Chemik 10: 616-619.

BOŻYM M., RAJMUND A. 2015. The study of cobalt leaching from soils, sewage sludges and composts using a one-step extraction. Ochrona Środowiska i Zasobów Naturalnych/ Environmental Protection and Natural Resources 26, 1(63): 1-6.

BROMAM., RAJFURM., KŁOSA., DUCZMALK., WACŁAWEKM. 2009. Wykorzystanie dżdżownic do oceny zanieczyszczenia gleb metalami ciężkimi, Chemia Dydaktyka Ekologia Metrologia 14, 1-2: 57-64.

CIESIELCZUK T., KUSZA G. 2009. Zawartość metali ciężkich w kompostach z odpadów jako czynnik ograniczający ich wykorzystanie do celów nawozowych. Ochrona Środowiska i Zasobów Naturalnych/Environmental Protection and Natural Resources 41: 347-354.

DAI, J., BECQUER, T., ROUILLER, J.H., REVERSAT, G., BERNHARD-REVERSAT, F., NAHMANI, J., LAVELLE, P. 2004. Heavy metal accumulation by two earthworm species and its relationship to total and DTPA-extractable metals in soils. Soil Biology and Biochemistry 36: 91-98.

GAJEWSKA J., GRĄDZIEL A., REKOSZ-BURLAGA H., MAKULEC G. 2007. Mikrobiologiczne aspekty żyzności gleby w doświadczeniu spod uprawy traw z dodatkiem dżdżownic (Aporrectodea caliginosa). Ochrona Środowiska i Zasobów Naturalnych/Environmental Protection and Natural Resources 32: 207-212.

HADAM A., OBIDOSKA G. 2009. Fitotoksyczność i genotoksyczność metali ciężkich zawartych w kompostach z odpadów miejskich. Ochrona Środowiska i Zasobów Naturalnych/Environmental Protection and Natural Resources 41: $332-340$
JESKE A., GWOREK B. 2011. Przegląd metod oznaczania biodostępności i mobilności metali ciężkich w glebach. Ochrona Środowiska i Zasobów Naturalnych/Environmental Protection and Natural Resources 49: 209-218.

KUCHARCZAK K., STĘPIEŃ $\quad$ W., GWOREK $\quad$ B. 2010. Kompostowanie odpadów komunalnych jako metoda odzysku substancji organicznej/ Ochrona Środowiska i Zasobów Naturalnych/Environmental Protection and Natural Resources 42: 240-254.

LI L., XU Z., WU J., TIAN G. 2010. Bioaccumulation of heavy metals in the earthworm Eisenia fetida in relation to bioavailable metal concentrations in pig manure. Bioresource Technology 101, 10: 3430-3436.

MA W.C. 2004. Estimating heavy metal accumulation in Oligochaete earthworms: A meta-analysis of field data. Bulletin of Environmental Contamination Toxicology 72: 663-670.

MOHEE R., SOOBHANY N. 2014. Comparison of heavy metals content in compost against vermicompost of organic solid waste: past and present. Resources, Conservation and Recycling 92: 206-213

RAO C. R. M., SAHUQUILLO A., LOPEZ SANCHEZ J.F. 2008. A Review of the different methods applied in environmental geochemistry for single and sequential extraction of trace elements in soils and related materials. Water Air Soil Pollution 189: 291-333

Rozporządzenie Ministra Rolnictwa i Rozwoju Wsi z dnia 18 czerwca 2008 roku w sprawie niektórych przepisów ustawy o nawozach i nawożeniu (Dz. U. nr 119, poz. 765).

SAXE, J.K., IMPELLITTERI, C.A., PEIJNENBURG, W.J.G.M., ALLEN, H.E. 2001. Novel model describing trace metal concentrations in the earthworm, Eisenia andrei. Environmental Science and Technology 35: 4522-4529.

SULEIMAN H., RORAT A., GROBELAK A., GROSSER A., MILCZAREK M., PŁYTYCZ B., KACPRZAK M., VANDENBULCKE F. 2017. Determination of the performance of vermicomposting process applied to sewage sludge by monitoring of the compost quality and immune responses in three earthworm species: Eisenia fetida, Eisenia andrei and Dendrobaena veneta. Bioresource Technology 241: 103-112. 